NBER WORKING PAPER SERIES

\title{
POST-DURBAN CLIMATE POLICY ARCHITECTURE BASED ON LINKAGE OF CAP-AND-TRADE SYSTEMS
}

\author{
Matthew Ranson \\ Robert N. Stavins \\ Working Paper 18140 \\ http://www.nber.org/papers/w18140
NATIONAL BUREAU OF ECONOMIC RESEARCH
1050 Massachusetts Avenue
Cambridge, MA 02138
June 2012

We are grateful for comments we received from Blair Beasley, Dallas Burtraw, Denny Ellerman, Robert Hahn, Sheila Olmstead, William Pizer, Robert Stowe, Tom Tietenberg, and participants in a workshop held at the University of Chicago Law School. The authors are responsible for all remaining errors. The views expressed herein are those of the authors and do not necessarily reflect the views of the National Bureau of Economic Research.

NBER working papers are circulated for discussion and comment purposes. They have not been peerreviewed or been subject to the review by the NBER Board of Directors that accompanies official NBER publications.

(C) 2012 by Matthew Ranson and Robert N. Stavins. All rights reserved. Short sections of text, not to exceed two paragraphs, may be quoted without explicit permission provided that full credit, including (c) notice, is given to the source. 
Post-Durban Climate Policy Architecture Based on Linkage of Cap-and-Trade Systems

Matthew Ranson and Robert N. Stavins

NBER Working Paper No. 18140

June 2012

JEL No. Q28,Q38,Q48,Q5,Q58

\begin{abstract}
$\underline{\text { ABSTRACT }}$
The outcome of the December 2011 United Nations climate negotiations in Durban, South Africa, provides an important new opportunity to move toward an international climate policy architecture that is capable of delivering broad international participation and significant global CO2 emissions reductions at reasonable cost. We evaluate one important component of potential climate policy architecture for the post-Durban era: links among independent tradable permit systems for greenhouse gases. Because linkage reduces the cost of achieving given targets, there is tremendous pressure to link existing and planned cap-and-trade systems, and in fact, a number of links already or will soon exist. We draw on recent political and economic experience with linkage to evaluate potential roles that linkage may play in post-Durban international climate policy, both in a near-term, de facto architecture of indirect links between regional, national, and sub-national cap-and-trade systems, and in longer-term, more comprehensive bottom-up architecture of direct links. Although linkage will certainly help to reduce long-term abatement costs, it may also serve as an effective mechanism for building institutional and political structure to support a future climate agreement.
\end{abstract}

\author{
Matthew Ranson \\ Harvard University \\ matthew_ranson@hksphd.harvard.edu \\ Robert N. Stavins \\ JFK School of Government \\ Harvard University \\ 79 JFK Street \\ Cambridge, MA 02138 \\ and NBER \\ robert_stavins@harvard.edu
}




\title{
Post-Durban Climate Policy Architecture Based on Linkage of Cap-and-Trade Systems
}

\author{
Matthew Ranson and Robert N. Stavins ${ }^{1}$
}

\section{INTRODUCTION}

Twenty years ago, with the signing of the 1992 United Nations Framework Convention on Climate Change (UNFCCC) in Rio de Janeiro, the nations of the world agreed to launch a process aimed at taking action against the risks posed by global climate change. Some limited progress has been made towards that goal: cap-and-trade systems for greenhouse gases are in place or under development in the European Union, Switzerland, Australia, New Zealand, South Korea, California, the northeastern United States, and several Canadian provinces; Japan and several Chinese cities and provinces are considering implementing such systems; and a global emission reduction credit scheme - the Clean Development Mechanism - has an important constituency in the world's developing countries. However, despite these initial steps, international negotiations have not achieved their central objective: developing a climate policy architecture that is capable of delivering broad international participation and significant global $\mathrm{CO}_{2}$ emissions reductions at reasonable cost (Posner and Weisbach 2010).

The recent UNFCCC talks in Durban, South Africa, in 2011, provide an important opportunity to frame a new approach to this exceptionally difficult global commons problem. A key product of the Durban negotiations is the "Durban Platform for Enhanced Action", a non-binding agreement that calls for a new climate treaty to be reached by 2015 that brings all countries under the same legal regime by 2020. Because this agreement departs from the long-standing UNFCCC division of the world's countries into those with serious emissions-reduction responsibilities (the Annex I countries) and those with no responsibilities whatsoever, it opens up the negotiation process to new thinking about international climate policy architecture.

In this article, we evaluate one important component of international architecture for the postDurban era: links among regional, national, and sub-national tradable permit systems for greenhouse gases. Because linkage allows emitters in high-cost cap-and-trade systems to meet their compliance obligations by purchasing allowances or credits from systems with lower marginal abatement costs, it reduces the overall cost of achieving a given global emissions target (Jaffe and Stavins 2010). ${ }^{2}$ Due to this reduction in aggregate costs, there is tremendous interest - indeed pressure - to link existing and planned cap-and-trade systems, and in fact, a number of links already or will soon exist.

\footnotetext{
${ }^{1}$ Ranson was a Ph.D. student in Public Policy at Harvard University when this article was written; he is now a Senior Analyst at Abt Associates; Stavins is the Albert Pratt Professor of Business and Government at the John F. Kennedy School of Government, Harvard University, University Fellow of Resources for the Future, and Research Associate of the National Bureau of Economic Research. Section 2 of the paper draws upon Jaffe, Ranson, and Stavins (2009), while Section 4 draws - in part - upon Aldy and Stavins (2012a). We are grateful for comments we received from Blair Beasley, Dallas Burtraw, Denny Ellerman, Robert Hahn, Sheila Olmstead, William Pizer, Robert Stowe, Tom Tietenberg, and participants in a workshop held at the University of Chicago Law School. The authors are responsible for all remaining errors.

${ }^{2}$ As Metcalf and Weisbach (2012) explain, international links can also be established among national policies (such as carbon taxes, performance standards, and technology standards) that do not involve direct trading of emissions allowances or credits. However, as Metcalf and Weisbach (2012) and Hahn and Stavins (1999) argue, such nontrading links are more challenging; and current political and business interest focuses mainly on linking tradable permit systems. Therefore, our exclusive focus in this paper is on linkage among trading instruments in the wake of the Durban Platform.
} 
Based on recent political and economic experience with linkage between tradable permit systems, we draw several preliminary conclusions about the near-term and long-term roles that linkage may play in post-Durban climate policy architecture. Because the outline of a decentralized system of direct and indirect linkages is already emerging, it is possible that in the absence of a top-down international agreement, such a collection of linkages will become the de facto near-term architecture for post-Durban international climate policy. Such a system has considerable promise for improving market stability while a broader international climate agreement is being negotiated. However, because direct linkages are currently planned only between systems in highly developed nations, and because most cap-and-trade systems have placed limits on the use of emissions reduction credits (which allow access to inexpensive abatement opportunities in developing countries), the near-term cost savings from this ad hoc system of links may be modest. Nonetheless, this system of linkages could still play an important near-term role by providing the institutional and political foundation for a future climate architecture. Additionally, in the longer term, linkage could provide substantial cost savings while serving as either the decentralized framework for an organic, bottom-up architecture, or as a component of a larger top-down climate architecture.

\section{THEORY OF LINKAGE}

We begin by describing different types of international linkages and explaining how these can affect policy considerations such as cost effectiveness, distribution of cost burdens, and national sovereignty and control. ${ }^{3}$

\subsection{TYPES OF LINKAGE}

The economic and environmental effects of linking different systems depend on the form of the link. One key distinction is between direct and indirect linkage (Jaffe, Ranson, and Stavins 2009).

\subsubsection{DIRECT LINKAGE}

Direct linkage between two systems occurs when one or both systems allow regulated entities to meet their compliance obligations by surrendering allowances or credits obtained from the other system. These direct links can be two-way (bilateral or multilateral) or one-way (unilateral).

Two-way direct linkage occurs when two cap-and-trade systems choose to recognize each other's allowances. Because of the arbitrage opportunity posed by different allowance prices, regulated entities in the system with the higher allowance price will purchase allowances from the lower price system. As a result, emissions in the higher price system will increase, but emissions from the lower price system will decrease by the same amount. This flow of allowances will cause allowance prices to increase in the lower price system and to decrease in the higher price system until - in principle - they converge to a common intermediate price.

One-way direct linkage occurs when a cap-and-trade (CAT) system recognizes credits from an emissions-reduction-credit (ERC) system ${ }^{4}$ or from another CAT system. In the former case, if the price of allowances is higher than the price of credits, then regulated entities in the CAT system have an incentive to purchase credits. This will increase the price of credits and reduce the price of allowances,

\footnotetext{
${ }^{3}$ Jaffe, Ranson, and Stavins (2009) present a more comprehensive treatment of the theory of linkage.

${ }^{4}$ An ERC system awards saleable credits to firms which implement voluntary projects that reduce greenhouse gas emissions relative to what emissions would have been under a counterfactual business-as-usual scenario. A prominent example of an ERC system is the Clean Development Mechanism, described below in Section 3.
} 
leading prices in the two systems to converge. However, if the initial allowance price is lower than the credit price, then CAT participants will not have any reason to purchase credits, and the one-way link will have no effect on prices or the distribution of emissions. Thus, a one-way link between a cap-and-trade system and a credit system ensures that the CAT system's allowance price never exceeds the price of credits.

One-way direct linkage can also occur when one CAT system recognizes allowances from a different CAT system. As in the case described above, this type of one-way linkage ensures that allowance prices in the first CAT system never exceed allowance prices in the CAT system whose allowances it recognizes.

Governments may place limits on inter-system trading that prevent full convergence of allowance prices. For example, a government may limit the quantity of external allowances that can be used to demonstrate compliance in its own system. Alternatively, an "exchange rate" may be applied to the price of allowances or credits from other systems. Such a requirement might be used to reduce inter-system trading or to ensure that trading with other systems leads to a net reduction in emissions.

\subsubsection{INDIRECT LINKAGES}

Indirect linkages occur when two systems link directly to a common third system. Even though neither system directly links to the other, the indirect linkage created by trading with the common system allows differences in the supply and demand for allowances to propagate between the original two systems.

An important type of indirect linkage occurs when two cap-and-trade systems both create direct one-way links to the same ERC system. As a result of these links, entities in the two CAT systems will compete for the ERC system's credits. If the price of credits is lower than the price of allowances in both systems, then this indirect linkage can lead prices in all three systems to converge. As a result, developments in the market in one of the CAT systems can affect the allowance price and emissions level in the other CAT system.

A series of bilateral (two-way) linkages between several CAT systems will also result in indirect linkage. Such a system will have the same effects as direct multilateral linkage among all of the systems. For example, if System A has a two-way link with System B, which has a two-way link with System C, then trading will - again, in principle - lead allowance prices to converge across all three systems, despite the fact that $\mathrm{A}$ and $\mathrm{C}$ are not directly linked.

\subsection{IMPLICATIONS OF LINKING}

Linkage can affect overall cost-effectiveness, the distribution of economic impacts, national control over policy design, and the incentives that nations face in setting domestic emissions reduction targets. Each of these factors has implications for the role that linkage may play in a post-Durban international policy architecture (Jaffe, Ranson, and Stavins 2009).

\subsubsection{COST EFFECTIVENESS}

The most important benefit of linkage is to lower the aggregate costs of emissions reductions by allowing firms in high-cost systems to pay for less expensive abatement opportunities in lower-cost systems. The improvement in cost-effectiveness will be greatest when the two systems face very different marginal abatement costs. Furthermore, by enlarging the scope of the relevant market, linking can improve market liquidity, reduce volatility in prices, and lessen concerns about market power. 
However, linkage can also have detrimental effects on the effectiveness of domestic climate policies. A key concern is the problem of "additionality": whether purchasing credits from an emissionsreduction-credit system truly reduces overall emissions. This problem arises from the difficulty of defining a counterfactual baseline against which to measure the effects of projects intended to reduce greenhouse gas emissions. If linkage allows regulated firms in a cap-and-trade system to purchase ERC credits from emissions reduction projects that would have occurred anyway, then linkage may actually cause aggregate emissions to increase (or to decrease less than they otherwise would have).

\subsubsection{DISTRIBUTION OF POLICY IMPACTS}

Linkage can also change the distributional impacts of GHG policies on regulated firms and the consumers that they serve. Whether a firm benefits or suffers from a new link depends on: (1) whether the firm is a net seller or net buyer of allowances, and (2) whether the firm is located in the higher or lower price system. For example, after a link to a system with a higher price, net sellers in the lowerprice system will benefit from the opportunity to sell more allowances, and to sell them at the higher postlinkage price. However, net buyers in the lower-price system will have to pay a higher price after linking, making them worse off. Thus, although linkage improves aggregate welfare in both systems, it can also create individual winners and losers in both systems.

The distributional effects of linkage also depend on the type of systems that are linked. For example, the creation of a one-way link between a cap-and-trade system and an emission-reduction-credit system can only benefit participants in the credit system, since these participants do not face mandatory emissions targets and thus can only benefit from the opportunity to sell emissions credits at higher prices. Hence, there is unanimous and enthusiastic support for the Clean Development Mechanism from the UNFCCC's non-Annex I countries.

\subsubsection{NATIONAL CONTROL}

Because linkage exposes a domestic system to the design features and market developments of any system to which it is linked, linkage can reduce national control over the economic and environmental impacts of domestic climate change policies. However, the degree to which domestic systems lose control depends on whether links are two-way or one-way. For example, cost-containment measures — such as banking, borrowing, offsets, or safety-valve provisions - will propagate completely across a two-way link between two cap-and-trade systems. In contrast, under a one-way linkage, costcontainment measures will propagate only to the system that accepts the other's allowances. ${ }^{5}$

\subsubsection{INCENTIVES FOR SETTING CAPS}

An additional concern about linkage is that it changes the incentives that jurisdictions face when setting their respective emissions caps (Helm 2003). Because a link can affect the allowance price within a linked jurisdiction, it can alter the fundamental tradeoff a government faces between the value it can create by issuing additional allowances and the marginal environmental damage that can arise from issuing such allowances. By expanding the scope of the allowance market, linkage can reduce the impact that the issuance of additional allowances has on allowance prices, and therefore on the value of existing allowances. Further, by allowing nations with high domestic emission reduction costs to purchase less expensive emission reductions from other systems, linking can reduce the costs that such nations would face in committing to more stringent caps, thereby partially offsetting some of these effects.

For example, when a small cap-and-trade system establishes a direct link with a larger cap-andtrade system, the administrator of the smaller system may be tempted to issue a larger number of

\footnotetext{
${ }^{5}$ Technically speaking, some price effects of cost-containment measures do propagate in both directions of a oneway linkage, via supply and demand effects in the linking and target systems.
} 
allowances into order to raise government revenues or benefit domestic firms. Alternatively, linkage to the larger allowance market may allow the smaller system to tighten its cap dramatically, achieving its targets by displacing costs onto foreign firms in the linked system.

\section{Characteristics of EXISTing ANd Proposed Linkages}

Despite the hiatus in the United States of serious consideration of a national $\mathrm{CO}_{2}$ cap-and-trade system, such systems are in place or under development in the European Union, Switzerland, Australia, New Zealand, South Korea, California, the northeastern United States, and several Canadian provinces, and are under consideration in Japan and parts of China. Additionally, a global emission reduction credit scheme (the Clean Development Mechanism) has an important constituency of supporters in the world's developing countries. In this section, we review these systems and describe existing and proposed links among them.

\subsection{LinKAgE AMONG EXISTING TRADING SYSTEMS}

Because governments face strong economic and political incentives to link to other systems, there are already a number of links established or proposed between existing tradable GHG (mostly $\mathrm{CO}_{2}$ ) permit systems.

\subsubsection{EMISSIONS TRADING UNDER ARTICLE 17 OF THE KYOTO PROTOCOL}

Under the Kyoto Protocol, each Annex I country took on a quantitative emissions target for the 2008-2012 compliance period. These emissions targets are expressed in Assigned Amount Units (AAUs). Under Article 17 of the Protocol, AAUs may be bought and sold by national governments, with the condition that each government must have a sufficient number of AAUs at the end of the compliance period to cover its actual emissions (United Nations 1998, at 3(10)). When two governments exchange AAUs, they create an implicit link between their domestic climate policies.

An important obstacle to the successful operation of such a system is that by its very nature, the trading is among nations (Hahn and Stavins 1999). Unlike private firms, nation-states are not simple cost-minimizers, and so there is no reason to anticipate that competitive pressures will lead to equating of marginal abatement costs across countries. Furthermore, even if nations did try to minimize costs, they would not have sufficient information about the marginal abatement costs of domestic firms to define their own national aggregate marginal cost functions. Thus, such a system does not have the costeffectiveness property ordinarily associated with tradable permit system among firms, and the notion of linkage via trading between countries may be more of a metaphor than a practical policy. To date, sales of AAUs have been modest relative to sales of other types of credits (Reuters 2011; U.S. Energy Information Administration 2011).

\subsubsection{CLEAN DEVELOPMENT MECHANISM}

The Kyoto Protocol's Clean Development Mechanism (CDM) is the world's largest emissionreduction-credit system. Under the CDM, firms and other entities in non-Annex I (developing) countries can be awarded certified emission reduction (CER) credits for conducting voluntary projects that reduce greenhouse gas emissions. These projects can take a variety of possible forms, such as building new wind farms, installing more energy efficient equipment in manufacturing facilities, or capturing methane from landfills. CERs can then be purchased by regulated emitters in Annex I counties for use in meeting their domestic emissions commitments. CERs could also be used for entities covered by cap-and-trade systems in countries that are not Parties to the Protocol (in particular, the United States). 
From the perspective of the developing countries, the CDM provides a mechanism for financing "sustainable development." From the perspective of the industrialized countries, the CDM provides a means to engage developing countries in the control of GHG emissions while simultaneously reducing the costs of achieving domestic emissions targets. Because it tends to be much less expensive to construct new low-carbon energy infrastructure in developing nations than to modify or replace existing infrastructure in industrialized countries (Wara, 2007), international trading in CERs could significantly reduce the aggregate cost of compliance with the Kyoto Protocol.

A number of cap-and-trade programs explicitly allow the use of CDM credits, including existing systems in the European Union, Switzerland, and New Zealand, as well as a future system in Australia (see below). Most CDM projects have been funded by European parties: investors in the United Kingdom have sponsored 30\% of all CDM projects, Swiss investors have sponsored 20\%, Japanese investors 10\%, Dutch 10\%, Swedish 7\%, and German 4\% (UNFCCC 2012a).

The CDM has accounted for annual $\mathrm{CO}_{2}$-equivalent reductions of 278 million tons, about 1 percent of annual global emissions of $\mathrm{CO}_{2}$ (U.S. Energy Information Administration 2011). ${ }^{6}$ The largest shares of CERs have been generated in China (52\%) and India (16\%), with Latin America and the Caribbean making up another 15\% of the total, Brazil (at 7\%) being the largest CER producer in that region (World Bank, 2010). Of the CERs expected to be generated by projects in the CDM pipeline by 2012, 35\% are for renewables, $28 \%$ are for $\mathrm{HFC}$ and $\mathrm{NO}_{2}$ reduction, $20 \%$ are for methane reduction, and the remaining $18 \%$ are for electricity generation, fuel switching, and other projects. ${ }^{7}$

As an emission-reduction-credit (ERC) system, the CDM raises important concerns about additionality, i.e., the problem of whether basing credits on an unobservable hypothetical baseline leads to credits being granted for emission reductions that would have occurred in any case. Empirical analysis has validated these concerns, with estimates that up to $75 \%$ of claimed reductions would have occurred in the absence of the program (Zhang and Wang 2011).

An additional concern has centered on the fact that nearly 30\% of average annual CERs have come from the destruction of HFC-23, a potent GHG that is a by-product of the manufacture of certain refrigerant gases. It is very inexpensive to destroy HFC-23, and companies can earn nearly twice as much from the sale of CDM credits as they can from selling respective refrigerant gases (Wara, 2007). As a result, it has been argued that plants were being built simply for the purpose of generating CERs from destruction of HFC-23. Because of this, beginning in 2013, CERs from HFC-23 destruction will not be valid for purposes of compliance with the EU ETS (see below).

As negotiations continue regarding the details of a second commitment period for the Kyoto Protocol, the CDM will most likely continue to function in any case (Bodansky 2011). However, a variety of proposals have been put forward to improve its structure and implementation, many targeted at increasing the additionality of approved projects (Hall, Levi, Pizer, and Ueno 2010). There have also been discussions of alternative mechanisms for engaging developing countries, such as "New Market Mechanisms" for sectoral crediting.

\subsubsection{JOINT IMPLEMENTATION}

Joint Implementation (JI) is another Kyoto Protocol flexibility mechanism. It allows entities in Annex I countries to generate and sell offset credits - known as Emission Reduction Units (ERUs) - to one another (Aldy and Stavins 2012b). Like the CDM, JI is a project-based ERC system whose credits

\footnotetext{
${ }^{6}$ Note that carbon sequestration projects of forestation and reduced deforestation are not included in the CDM under the Kyoto Protocol's first commitment period, 2008-2012.

${ }^{7}$ See http://www.cdmpipeline.org/cdm-projects-type.htm.
} 
raise concerns about additionality, although the concerns are somewhat different since countries that can participate in JI projects have caps under the Kyoto Protocol.

The market for ERUs has been less robust than the market for CERs. As of April, 2012, host countries had issued 131 million ERUs. Of the 542 approved projects, 163 were based in Ukraine, 144 in Russia, 59 in the Czech Republic, 39 in Bulgaria, and 25 in Poland, with the remainder primarily in Europe (UNEP Risoe Centre 2012).

\subsubsection{EUROPEAN UNION EMISSIONS TRADING SCHEME}

The European Union Emission Trading Scheme (EU ETS) is a downstream $\mathrm{CO}_{2}$ cap-and-trade system that is by far the world's largest carbon pricing regime (European Commission 2012a). This system, which was adopted in 2003, covers about half of $\mathrm{CO}_{2}$ emissions from thirty European countries. ${ }^{8}$ The EU ETS has been implemented in phases: a first (pilot) phase from 2005 to 2007, a second (Kyoto) phase from 2008 to 2012, and a scheduled third phase from 2013 to 2020. Although the first phase allowed trading only in carbon dioxide, the second phase broadened the program to include some other GHGs from certain industrial sectors, such as nitrous oxide emissions from nitric acid production. The 11,500 regulated sources include large sources such as oil refineries, combustion installations over 20 MWth, coke ovens, cement factories, and pulp and paper producers (Ellerman and Buchner 2007). Although EU ETS allowance prices averaged €22 in the second half of 2008, prices had fallen to €7 in 2012 as the economic recession brought reduced economic activity and decreased demand for allowances. ${ }^{9}$

The European Commission's Linking Directive allowed EU ETS participants to use CERs from the Clean Development Mechanism beginning in 2005 and ERUs from the Joint Implementation program beginning in 2008, although certain types of projects, such as land use change, forestry, and nuclear power, have not been eligible for credits (European Parliament 2004, p.18; European Commission 2005, p.17), and industrial gas destruction projects will cease to be eligible after 2013 (European Commission, 2011b). Because of these links, CER and ERU prices are heavily dependent on EU ETS allowance prices. $^{10}$

During the first and second trading periods, EU ETS member nations each set national limits on the use of credits as a percentage of total allowances, with limits ranging from 0 percent in Estonia to 20 percent in Lithuania and Spain (European Commission 2007c, p.2). In future trading periods, the European Commission has mandated that no more than half of the EU ETS overall emissions reductions target may be achieved through credits. Furthermore, for projects initiated in 2013 or later, the EU ETS will recognize CERs only from nations on the U.N.'s list of Least Developed Countries (most of which are in Africa), thereby eliminating projects from the countries that currently dominate the supply, most notably, China and India. CERs flowing from projects begun prior to 2013 in more developed nonAnnex I countries will continue to be allowed (European Commission 2011a).

\footnotetext{
${ }^{8}$ The EU ETS covers all 27 EU member states plus Iceland, Liechtenstein, and Norway. Iceland, Liechtenstein, and Norway joined the EU ETS in 2008, although sources in Iceland are not yet subject to an emissions cap.

${ }^{9}$ In addition, a set of "complementary policies," such as those aimed at increasing the use of renewable sources of energy, have had the effect of reducing emissions in one sector only to see them increase in other sectors, under the EU ETS umbrella, thereby accomplishing no additional net emissions reductions, but increasing aggregate costs (decreasing cost effectiveness) by maintaining heterogeneous marginal abatement costs, and reducing allowance prices in the EU ETS.

${ }^{10}$ See, for example: CarbonPositive (2007, 2008); Point Carbon Advisory Services (2007, p.3-4).
} 
To some degree, the EU ETS can itself be viewed as a large multilateral linkage among its member counties, in which each country recognizes allowances issued by all other members (Ellerman 2010, p.1). This was particularly true in the first and second trading periods, during which each country proposed its own individual emissions cap for review by the European Commission (Kruger, Oates, and Pizer 2007, p.115-116). This created incentives for individual countries to try to be generous with their allowances to protect their economic competitiveness (Convery and Redmond 2007). Not surprisingly, the result was an aggregate cap that — at least in Phase I - exceeded business-as-usual emissions. ${ }^{11}$ However, for future trading periods, caps have been determined through a more centralized process at the EU level (European Parliament 2009; European Commission 2012b).

\subsubsection{NORWEGIAN EMISSIONS TRADING SCHEME}

From 2005 to 2007, Norway operated an Emissions Trading Scheme (ETS), which covered 10 to 15 percent of national $\mathrm{CO}_{2}$ emissions and imposed a cap equal to 95 percent of 1998-2001 levels. ${ }^{12}$ The system included a one-way linkage with the EU ETS, which allowed Norwegian firms to meet their compliance obligations by purchasing emissions permits from the EU ETS (Bruvoll and Dalen 2009, p.18). In 2007, the three non-EU member countries of the European Economic Area - Norway, Iceland, and Liechtenstein - joined the EU ETS through the adoption of the EU ETS Directive (2003/87/EC as amended) into the European Economic Area (EEA) agreement (European Commission 2007b; Norway Ministry of the Environment 2009, p.36-37). ${ }^{13}$ With this agreement, Norway and the other EEA members agreed to follow the same process for setting national caps as the EU member states.

\subsubsection{SWISS $\mathrm{CO}_{2} \mathrm{ACT}$}

Since 2008, Switzerland has operated a quasi-voluntary cap-and-trade system based on the authority of its $\mathrm{CO}_{2}$ Act. Under this program, companies can be granted exemption from a mandatory $\mathrm{CO}_{2}$ tax on fossil fuels in exchange for taking on a legal commitment under the cap-and-trade system (Mace et al. 2008, p.7-8). Under the Swiss system, companies may meet up to eight percent of their emissions targets using CDM and JI credits (Swiss FOEN 2007). Although Swiss and EU participants cannot currently use each other's allowances, the Swiss government has begun negotiations with the European Commission to create a link between the Swiss trading program and the EU ETS, mostly likely starting in 2014 (Council of the European Union 2010; PointCarbon 2012b).

\subsubsection{NEW ZEALAND EMISSIONS TRADING SCHEME}

In January, 2008, the New Zealand Emissions Trading Scheme (NZ ETS) was launched. The forestry sector entered the program first, in 2008, and stationary energy, industrial, and liquid fuel fossil fuel sectors joined in 2010. Early evidence suggests that the forestry component has deterred deforestation, although international policy and consequent price uncertainty are major problems for investment (Karpas and Kerr 2011). The waste (landfills) sector is scheduled to enter in 2013, and agriculture - which accounts for nearly half of New Zealand's gross emissions - is scheduled to enter in $2015 .^{14}$ Thus, the intention of the system is to include all sectors of the economy and all greenhouse gases by 2015 (Emissions Trading Scheme Review Panel 2011, p.6). The NZ ETS features free allocation of allowances, with special protections (output-based updating allocations) for emission-intensive, trade-

\footnotetext{
11 Due to a variety of factors, including the economic recession and the ability of regulated entities to bank allowances into Phase III, it is difficult to assess the system’s performance in Phase II.

12 The Norwegian ETS was designed to be compatible with the EU ETS (Mace et al. 2008, p.6).

${ }^{13}$ Iceland and Liechtenstein did not previously have cap-and-trade systems.

${ }^{14}$ See: http://www.climatechange.govt.nz/emissions-trading-scheme/
} 
sensitive sectors, as well as a safety valve that allows participants to meet their obligations by paying a fee of NZ\$25 per ton (Emissions Trading Scheme Review Panel 2011, p.6; New Zealand Parliament 2011, at 222C). Additionally, a recent five-year government review recommended that the agriculture sector face a lower price as it enters the system (Emissions Trading Scheme Review Panel 2011).

Currently, the NZ ETS allows participants to use an unlimited number of credits from the CDM and JI programs, as well as AAU allowances converted from other UNFCCC signatories (NZ Ministry for the Environment 2007, p.46-48). However, certain categories of offset credits are not eligible, such as those based on HFC-23 and $\mathrm{NO}_{2}$ industrial gas destruction (NZ Ministry for the Environment 2012). The ETS also includes several features intended to protect participants from the potential price effects of international demand for its allowances (known as New Zealand Units, or NZUs). The establishing legislation prohibits export of NZUs if the total number of NZUs held within the country falls below 90 percent of the initial allocation for that trading period. Additionally, in response to the recession, in 2009 the New Zealand government prohibited participants in all sectors except forestry from exporting any allowances until 2013 (New Zealand Parliament 2011, at 17,222G).

Some features of the New Zealand ETS, particularly the way that allowances are allocated, were chosen for compatibility with Australia's previously proposed Carbon Pollution Reduction Scheme (CPRS). Although the CPRS never became law, the possibility of linking to a future Australian system was - and is - an important consideration for the New Zealand ETS, especially in light of the close trade relationship between the two countries (ETS Review Panel 2011, p.28). In 2011, the New Zealand government announced plans to establish a two-way linkage with Australia's forthcoming emissions trading program (Australia's 2011 Clean Energy Act; see discussion below), beginning in 2015 (Combet and Groser 2011). The details of this linkage have not yet been finalized.

Establishing a direct linkage between the New Zealand ETS and the EU ETS poses greater challenges. Because forest sink credits are a major part of the New Zealand ETS but are not allowed by the EU ETS, the creation of a direct link between the two systems is unlikely in the near future (New Zealand Herald 2011). However, as a result of its direct link to the CDM, the New Zealand ETS does have an indirect linkage to the EU ETS. Because non-forestry New Zealand sources are required to surrender only one allowance per two units of emissions until 2013, the current effective price of NZ allowances is very low.

\subsubsection{REGIONAL GREENHOUSE GAS INITIATIVE}

The Regional Greenhouse Gas Initiative (RGGI) is a downstream cap-and-trade program that limits $\mathrm{CO}_{2}$ emissions from power sector sources in nine northeastern U.S. states (Connecticut, Delaware, Maine, Maryland, Massachusetts, New Hampshire, New York, Rhode Island, and Vermont). ${ }^{15}$ Like the EU ETS, RGGI can be envisioned - to some degree - as a linked set of state-level cap-and-trade programs.

The system is both narrow in its sectoral coverage and unambitious in terms of its emissions reduction objectives. RGGI took effect in 2009, after approval by individual state legislatures, and set a goal of lowering emissions to 10 percent below 2009 levels by 2019. It was originally anticipated that meeting this goal would require a reduction of approximately 35 percent below business-as-usual emissions levels. However, due the combined effects of the economic recession and drastic declines in natural gas prices relative to coal prices, the cap is no longer binding and is unlikely to become binding

\footnotetext{
${ }^{15}$ In May of 2011, New Jersey Governor Chris Christie announced that his state would withdraw from the system.
} 
through 2020, unless the cap trajectory is adjusted (Regional Greenhouse Gas Initiative 2010a; Aldy and Stavins 2012b). ${ }^{16}$

The Model Rule governing RGGI's implementation allows for two types of one-way linkages. First, covered sources may meet up to 3.3 percent of their compliance obligations using allowances generated by certain types of offset $\mathrm{CO}_{2}$ projects located in one of the RGGI states, or in another U.S. jurisdiction that has completed a memorandum of understanding with the RGGI states (Regional Greenhouse Gas Initiative 2007, p.63,105). ${ }^{17}$ The 3.3 percent limitation was chosen so that no more than half of all emissions reductions between 2009 and 2020, relative to projected baseline emissions at the time the Model Rule was written, would be achieved using offsets (Regional Greenhouse Gas Initiative 2006a). To address uncertainty about future abatement costs, the rule includes price triggers that allow greater use of offsets if average annual allowance prices exceed certain thresholds. If the price exceeds \$7 (in 2005\$), sources may use offsets for up to 5 percent of their compliance obligations, and if the price exceeds a "stage two threshold price" that begins at \$10 in 2005 and increases by about 2 percent each subsequent year, then sources may use offsets for up to 10 percent of their compliance obligations (Regional Greenhouse Gas Initiative 2007, p.17-18,63).

The second type of linkage allowed by RGGI is one-way linkage to other international CAT and ERC systems. If annual allowance prices exceed the "stage two threshold price", then RGGI sources may satisfy their compliance obligations using CERs from UNFCCC emission-reduction-credit programs or allowances from any other cap-and-trade system outside the United States (Regional Greenhouse Gas Initiative 2007, p.105-106).

As of the spring of 2012, no applications for approval for offset projects have ever been submitted to RGGI (Regional Greenhouse Gas Initiative $\mathrm{CO}_{2}$ Allowance Tracking System 2012a), because of the low RGGI allowance price (Regional Greenhouse Gas Initiative 2010b; Regional Greenhouse Gas Initiative $\mathrm{CO}_{2}$ Allowance Tracking System 2012b). Furthermore, because RGGI prices have remained far below the $\$ 10$ stage two threshold price, RGGI sources have never been permitted to use CERs or other CAT systems' allowances.

\subsection{Possible Linkage among Future Trading Systems}

Several new cap-and-trade systems will come into effect in the near future. Although details of these systems remain to be determined through promulgation of specific regulations, the respective authorizing legislation provides insights into the likely future role of linkage in each system. ${ }^{18}$

\subsubsection{AUSTRALIA'S CLEAN ENERGY ACT OF 2011}

In 2011, Australia's government passed its Clean Energy Act, which imposes a carbon tax of approximately AUD\$25/ton for the period from 2012 to 2015, after which the tax is to be replaced by a cap-and-trade system (Australian Clean Energy Act 2011, at 100). The Act includes a number of features

\footnotetext{
${ }^{16}$ Allowance prices have reflected these realities, falling from approximately $\$ 3$ per ton of $\mathrm{CO}_{2}$ at the first auction in September, 2008, to the floor price of $\$ 1.93$ per ton in 2012 (RGGI COATS, 2012b). In response, RGGI states are considering lowering the emissions cap for the 2014 to 2020 period (PointCarbon, 2012a).

${ }^{17}$ The Revised Memorandum of Understanding between the RGGI states also allows offset credits from non-RGGI U.S. states with cap-and-trade systems (RGGI 2006b, p.2). However, this provision was not included in the Model Rule that serves as the basis for the state regulations.

${ }^{18}$ We exclude some systems from our analysis. As of early 2012, British Columbia, Manitoba, and Ontario have not yet finalized cap-and-trade regulations.
} 
directed at possible linkage with other systems. Import and export of allowances is allowed (Australian Clean Energy Act 2011, at 108,109), although the government may set charges on international allowances and credits of up to AUD\$15 in 2015, AUD\$16 in 2016, and AUD\$17.05 in 2017 (Australian Clean Energy International Unit Surrender Charge Act 2011, at 8).

Furthermore, the government is tasked specifically with developing regulations on the use of foreign allowances that take into account Australia's international objectives and obligations, the environmental integrity of Australia's system, and "the extent to which eligible international emissions units may be surrendered, accepted or used for the purposes of: (i) the Climate Change Response Act 2002 of New Zealand; or (ii) the European Union emissions trading scheme” (Australian Clean Energy Act 2011, at 123). As discussed above, Australia and New Zealand have announced plans to link their trading systems beginning in 2015, once Australia's carbon tax converts to a cap-and-trade system (Combet and Grocer 2011). Additionally, Australian and European Commission officials have begun negotiations to consider how Australia's system might be linked to the EU ETS (Combet 2012).

\subsubsection{CALIFORNIA's GLOBAL WARMING SOLUTIONS ACT OF 2006}

California's Global Warming Solutions Act of 2006 directed the California Air Resources Board (CARB) to promulgate regulations to achieve the goal of reducing the state's greenhouse gas emissions to 1990 levels by the year 2020, a very ambitious target by North American standards. In 2011, CARB finalized a rule that establishes a cap-and-trade system as the primary mechanism by which the state will achieve this goal, beginning in 2013 (California Air Resources Board 2011). The regulation includes several cost-containment measures, including banking of allowances and a strategic allowance reserve, as well as allowing for linkage to other systems (California Air Resource Board 2011).

Two types of links are allowed by current regulations governing the cap-and-trade system. First, facilities may use offsets (of any approved type) for up to eight percent of their compliance obligations (California Code of Regulations 10-5, at 95854). Initially, credit will only be given for offsets from U.S. based projects involving forestry, dairy digesters, and destruction of ozone-depleting substances. However, the regulations create a framework for possible future linkage to CDM, JI, and other international ERC programs (California Air Resources Board 2011), and California has completed a joint memorandum of understanding with Chiapas, Mexico, and Acre, Brazil, that could allow the use of avoided deforestation offsets from these two states as soon as 2015 (Morris, Richardson, and Riddle 2011). Second, the regulations allow for unrestricted use of allowances from directly linked cap-andtrade systems (California Code of Regulations 10-5, at 95821,95941-95942). In March, 2012, regulations were proposed that would create a two-way direct link with Quebec's cap-and-trade system, although this linkage was delayed by a legislative subcommittee in 2012 (California Air Resources Board 2012, at 95943; PointCarbon 2012c). Links with other U.S. states and Canadian provinces may come later via the Western Climate Initiative. ${ }^{19}$

\subsubsection{QUEBEC'S CAP-AND-TRADE SYSTEM}

In 2011, the Quebec government adopted regulations establishing a cap-and-trade system for industrial facilities emitting more than 25,000 tons of $\mathrm{CO}_{2}$ per year (Quebec Office of the Minister of Sustainable Development, Environment, and Parks 2011). This system, which will begin capping emissions starting in 2013, is explicitly based on design criteria established by the Western Climate Initiative (Emissions Trading Association 2012, p.1). Indeed, the regulation allows for linkage with other cap-and-trade systems with which the government of Quebec has concluded an agreement, and Quebec

\footnotetext{
19 The Western Climate Initiative originally was to include eleven western U.S. states and Canadian provinces, and now is likely to begin with California, Ontario, and Quebec, which are contemplating linking their developing state/provincial $\mathrm{CO}_{2}$ cap-and-trade systems beginning in 2013.
} 
plans to link to California's cap-and-trade system (Quebec Government 2011, at I.III.37). However, the Quebec system restricts facilities from using domestic offsets to cover more than eight percent of their emissions, and does not currently allow linking with international sources of offset credits, such as the CDM (Quebec Government 2011, at I.III.20(5), I.III.37; International Emissions Trading Association 2012a, p.11).

\subsubsection{ChINA’s EMISSIONS TRAding SySTEM PILOTS}

In late 2010, the Chinese government released its Twelfth Five-Year-Plan, which calls for the establishment of a national carbon emission trading system by 2015. The government has begun work to establish pilot cap-and-trade programs in the cities of Beijing, Tianjin, Shanghai, Chongqing, and Shenzhen, and the provinces of Hubei and Guangdong, by 2013 or 2014 (Han et al. 2012). Because the basic characteristics of these pilot systems (such as whether they will be mandatory or voluntary, whether the caps will be absolute or intensity-based, and what industries will be included) remain to be determined (Petherick 2012), it is not clear whether or how these trading programs might link to other cap-and-trade or credit systems.

\subsubsection{SOUTH KOREA'S CAP AND TRADE SYSTEM}

In May of 2012, South Korea's parliament voted to establish a cap-and-trade program that will take effect in 2015. The program will apply to companies whose annual emissions are greater than 125,000 metrics tons of $\mathrm{CO}_{2}$, as well as some smaller factories, buildings, and livestock producers (Bloomberg 2012). The government has not yet promulgated regulations governing offsets or linkage to other systems.

\subsubsection{AMERICAN CLEAN ENERGY AND SECURITY ACT OF 2009}

In 2009, the U.S. House of Representatives passed the American Clean Energy and Security Act (also known as the Waxman-Markey Bill), which would have established a national $\mathrm{CO}_{2}$ cap-and-trade system in the United States. Although the bill never became law, it offers some insight into U.S. political preferences regarding linkage with other systems. The bill would have allowed U.S. firms to use emissions allowances from foreign cap-and-trade systems, such as the EU ETS, but would have given the U.S. Environmental Protection Agency the option of establishing a limit on the percentage of a firm's emissions that could be covered by such foreign allowances (H.R. 2454 at 722(d)3, 728). The bill would also have allowed the use of both domestic and foreign (such as CDM) offset credits, with a combined quantitative limit of up two billion tons per year (compared with a total emissions cap of approximately five billion tons). Starting in 2018, the bill would have applied an exchange rate of 1.25:1 when redeeming foreign offsets (H.R. 2454 at 722(d)1,721(e)).

\section{The Durban Platform AND Its IMPLiCATIONS FOR LiNKAGE}

A considerable number of linkages have been established or are likely to be established among regional, national, and sub-national tradable permit systems. For better or worse, these linkages have been heavily influenced by the longstanding UNFCCC distinction between Annex I and non-Annex I responsibilities. In particular, because the UNFCCC institutional framework has not encouraged developing countries to establish cap-and-trade systems, all links to developing countries have been through the CDM - an emission-reduction-credit system with flaws related to lack of full additionality. However, the Durban talks have opened up an opportunity for a new international framework that could employ linkage to engage developing countries, reduce the global costs of emissions reductions, and develop an institutional framework for a future top-down or bottom-up international climate policy architecture. 


\subsection{The UNFCCC, THE Berlin MANDATE, AND THE Kyoto Protocol}

Article 3 of the 1992 UNFCCC established a key principle: "The Parties should protect the climate system for the benefit of present and future generations of humankind, on the basis of equity and in accordance with their common but differentiated responsibilities and respective capabilities. Accordingly, the developed country Parties should take the lead in combating climate change and the adverse effects thereof" (United Nations 1992, emphasis added). The countries considered to be “developed country Parties" were listed in an appendix to the 1992 Convention (Annex I) which included the members of the Organization for Economic Cooperation and Development (OECD) plus most of the emerging market economies of eastern Europe and the former Soviet Union.

Three years after the Rio conference, at the first Conference of the Parties of the Framework Convention (COP-1) in Berlin, the global community agreed to the "Berlin Mandate" (United Nations 1995). This agreement developed a specific interpretation of "common but differentiated responsibilities" by establishing the dichotomous distinction whereby the Annex I countries are to take on emissionreduction responsibilities, and the non-Annex I countries are to have no such responsibilities whatsoever.

The Berlin Mandate, subsequently codified in the 1997 Kyoto Protocol via numerical national targets for a limited set of countries, had wide-ranging, worldwide consequences. The dichotomous structure has driven up aggregate compliance costs to as much as four times their cost-effective level, because many opportunities for low-cost emissions abatement in emerging economies are taken off the table (Nordhaus 2008). More problematic, an institutional structure was thereby put in place that makes change and progress exceptionally difficult, if not virtually impossible.

\subsection{A New Approach Requiring Participation of All Parties}

At the December 2011 UN talks in Durban, South Africa (COP-17), the international community agreed to a negotiating process focused on the long-term participation of all parties in the effort to mitigate greenhouse gas emissions and combat climate change (United Nations 2011). In particular, they adopted the goal of reaching an agreement by 2015 that will bring all nations under the same legal regime by 2020.

This Durban Platform for Enhanced Action completely eliminates the Annex I/Non-Annex I (or industrialized/developing country) distinction. Nowhere in the text of the decision will one find phrases such as "Annex I" or "historical responsibility," which had long since become code words for emission targets applied exclusively to the richest countries.

Negotiators from around the world now have a challenging task before them: to identify a new international climate policy architecture that is consistent with the process, pathway, and principles laid out in the Durban Platform, while still being consistent with the UN Framework Convention. In other words, the challenge is to find a way to include all countries (or at least, the 20 largest national and regional economies that together account for upwards of $80 \%$ of global greenhouse gas emissions) in a structure that brings about meaningful emission reduction on an appropriate timetable at acceptable cost, while recognizing the different circumstances of nations in a way that is more subtle and sophisticated than the simple dichotomous distinction of years past.

Although the Durban Platform opens up a window to a variety of promising international policy architectures,${ }^{20}$ its implications for architectures based on linkage are particularly important. By lessening a key obstacle to the most meaningful international linkages - the absence of cap-and-trade systems in

\footnotetext{
${ }^{20}$ See, for example: Aldy and Stavins 2010; Posner and Weisbach 2010.
} 
developing countries - the Durban Platform has improved the chances of future direct linkages among tradable permit systems in developed and developing countries. Such linkages could serve a variety of roles in international climate policy architecture.

\section{Linkage as a Climate Policy Architecture}

We consider the role that linkage could play in international climate policy architecture. Our examination is informed both by political interest in and economic experience with linkage. The existing and planned links among regional, national, and sub-national climate change policies - as documented in Section 3 - provide preliminary evidence regarding both the near-term and long-term roles that linkage may play in global climate policy architecture.

\subsection{NEAR-TERM ROLE}

In the years since the ratification of the 1997 Kyoto Protocol, a patchwork system of linkages has evolved among independent regional, national, and sub-national climate policies. As described in above, the current set of existing and planned international links includes a number of direct connections: links between trading systems in Europe, including the EU ETS, the EEA countries, and (most likely in 2014) Switzerland; the planned links among the members of the Western Climate Initiative, including the recently announced linkage between California and Quebec; and the planned link between the New Zealand ETS and Australia's forthcoming cap-and-trade system. Additionally, Australia and the EU are in negotiations to link their systems, a development that could create an indirect linkage between the EU ETS and New Zealand's ETS. Furthermore, the CDM and JI offset markets provide a strong indirect linkage between the European systems and the New Zealand ETS, and, depending on future allowance prices, could provide an indirect linkage to RGGI.

This sample of existing and planned links hints at the outline of a near-term "system" that combines several regional, directly linked cap-and-trade systems, with some level of indirect connection via a common credit system, such as the CDM or a sectoral crediting program. Until a specific international agreement is realized, such a bottom-up, decentralized system may become the de facto structure for near-term to medium-term international climate policy architecture. ${ }^{21}$

Such a de facto near-term system could play two roles. First, it could provide economic benefits such as cost savings and market liquidity while (presumably) a future climate agreement is being negotiated. Second, by helping to build an institutional framework of coordination among different systems, near-term linkage could help with the political transition to a robust long-term international climate policy architecture. We discuss these roles in more detail in the following subsections.

\subsubsection{CAN LINKAGE PROVIDE NEAR-TERM COST SAVINGS AND MARKET LIQUIDITY?}

In the short term, linkage may provide two main economic contributions: creating cost savings, and improving market liquidity and stability. As discussed in Section 2, the key economic rationale for linking two systems is to lower the aggregate costs of emissions reductions. Because greenhouse gas emissions have the same effect on climate change regardless of where in the world they originate, linkage allows firms in high-cost systems to pay for less expensive abatement opportunities in lower-cost systems while still achieving the same overall environmental benefit. Furthermore, because linkage increases the number of market participants available to buy and sell allowances and credits, it can thicken markets and reduce problems with price volatility.

\footnotetext{
${ }^{21}$ The Durban Platform calls for an agreement to be reached by 2015 for implementation in 2020.
} 
Experience suggests that direct linkages between cap-and-trade systems does in fact help to improve market functioning. The best example of the economic benefits of direct linkage comes from the EU ETS. Although allowance markets during the EU ETS trial phase showed signs of thinness, more recent trading periods have had higher volumes and greater efficiency (Montagnoli and de Vries 2010).

However, although linkage can help with market functioning, the near-term cost savings from direct links between cap-and-trade systems may be modest. Because two-way links are currently planned primarily between systems in highly developed nations, direct links may not be able to help regulated firms take advantage of very low-cost abatement opportunities (such as those available in developing countries). Furthermore, direct linkages suffer from a climate policy irony: the links that are most attractive for economic reasons - those between systems with very different allowance prices (such as RGGI and the EU ETS) - may be politically the most difficult to establish, because of the large international capital flows that such links would generate.

Links with a credit system can also contribute to the near-term goals of cost-minimization and market liquidity. In principle, a near-term set of indirect links could yield much of the cost savings and other advantages of a broad set of multilateral links. This system of indirect links would preserve a high level of national control over domestic carbon markets, thus allowing countries to tailor policies to fit their specific political and economic circumstances.

In practice, the ability of credit systems - in particular, the CDM - to create meaningful indirect links between cap-and-trade systems has been mixed. On the positive side, allowance prices in the New Zealand ETS, which allows unlimited purchase of CDM offset credits, have been strongly influenced by developments in the CDM and the EU ETS (Reuters 2012). However, despite the potential cost-savings from linking to a credit system, some cap-and-trade systems (such as in California and Quebec) have chosen to allow only selected external credits. Others have imposed quantity limits on the use of external credits, have designed application procedures that make it difficult to receive approval for new offset projects, or have implemented trigger mechanisms that only allow the use of foreign offsets if domestic allowance prices exceed some pre-determined level. This general reluctance to allow links with credit systems (in particular, with the CDM) is motivated by concerns about additionality, as well as an emphasis on achieving domestic emissions reductions. Therefore, whether indirect links can improve the stability and cost-effectiveness of domestic carbon markets will depend largely on broader acceptance and use of credit systems such as the CDM.

Although indirect linkage has clear benefits, it could also have destabilizing effects on offset markets in developing countries. Such a situation could arise as the result of limits that many systems are placing on the use of external offset credits. Consider a simple example, depicted in Figure 1, in which the world economy contains only two systems: a cap-and-trade system, and an emission-reduction-credit system. Suppose that the cap-and-trade system limits the number of offset credits that domestic entities can use for compliance, and that this limit is binding. As a result, the ERC system will have an oversupply of emission reduction opportunities that would be profitable at current allowance prices, and the market for credits will fail to clear. The situation is potentially even worse when there are two or more cap-and-trade systems with binding limits on the use of external offsets. Because the market for offset credits will fail to clear, there will be multiple prices for credits, with prices depending on the allowance price in each separate cap-and-trade system. In either case, the markets would face problems with transparency, and the resulting uncertainty could create substantial business risks that might drive up the costs of emissions reductions. In particular, companies which make investments in offset projects would face the risk that they would be unable to sell their CERs at any price due to the binding limits on offset sales.

How likely is such a scenario? Table 1 summarizes limits on the use of offsets and credits for compliance in existing and planned systems. The table shows, for example, that after 2013, credits may 
make up no more than half of aggregate EU ETS emissions reductions. Other systems have also imposed limits. If nations pursue substantial emissions reduction goals while maintaining limits on offset credits, it is possible that limits on offsets will increasingly bind. The current (May, 2012) discount of CER prices relative to EU ETS allowance prices suggests that this may already be happening.

\subsubsection{Can Linkage Provide a Foundation for a Future Policy ARChitecture?}

Although most of the ongoing discussions about potential linkages focus on the economic benefits of linking systems with different marginal abatement costs, linkage may provide an additional set of benefits, which are fundamentally political. By helping to build an institutional framework of coordination among different systems, near-term linkage could help create a pathway to a robust longterm international climate policy architecture.

In the short term there will probably be several regional sets of directly linked systems, with some indirect linkage through the CDM or other offset/sectoral crediting programs. Based on the limited political evidence available to date, this system may transition towards a system with greater numbers of two-way and multilateral direct links. Such a system of linked cap-and-trade systems would preserve some national autonomy while requiring increased coordination of legislation, regulation, and institutions. Thus, in the same way that the General Agreement on Tariffs and Trade transitioned into the World Trade Organization, a bottom-up system of links could - in principle - provide the basic institutional framework for a broader climate agreement. The creation of a broad set of links could generate not only experience but some degree of mutual trust among nations, and could supply at least a natural starting point for diplomatic negotiations.

Of course, linkage could also create political and regulatory obstacles to a future agreement. Creating a linkage between two systems requires agreement about a variety of design characteristics, including the stringency of the cap in each system. Because linkage can make it difficult for countries to change such design characteristics, it might make it more difficult for countries to make the adjustments necessary to support some future climate agreement.

Linkage could help to support a future climate agreement in another way: by providing participation incentives for nations to adopt market-based climate policies. Major developed countries with cap-andtrade systems may be expected to attempt to use offset programs as both a carrot and stick to stimulate developing country participation.

The best example of this may be EU ETS policy towards CDM offsets from developing countries. Whereas between 2008 and 2012, the EU ETS allowed regulated entities to use CDM credits originating in any developing country, beginning in 2013, new CDM credits will only be allowed for projects originating in Least Developed Countries (thus excluding China and India). This policy shift is deliberate: recent EU documents state that "while initially the use of international credits was allowed for cost effective compliance, this has been complemented with the objective of actively using the leverage the EU possesses as the by far most important source of demand for international credits" (European Commission 2012c). Furthermore, the EU ETS website states that the "EU has set out a vision for the development of an international carbon market: the market is expected to develop through bottom-up linking of compatible domestic cap-and-trade systems. An OECD-wide carbon market is expected by 2015, which would be extended to include economically more advanced developing countries by 2020 . New sectoral crediting mechanisms would be a stepping stone to cap and trade for these developing countries." 22 Whether or not this EU linkage strategy will be effective is difficult to predict.

\footnotetext{
${ }^{22}$ See: http://ec.europa.eu/clima/policies/ets/linking/index_en.htm. Accessed 5/28/2012.
} 


\subsubsection{OBSTACLES TO NEAR-TERM LINKAGE}

It is important to keep in mind that a variety of political, institutional, and economic factors will determine the types of links that are formed in the near future. Recent political experience suggests that it has not been difficult to establish direct linkages between existing and planned cap-and-trade systems in developed countries. However, these direct linkages are occurring primarily between jurisdictions that already have strong economic, political, and/or geographic ties.

One obstacle to the establishment of additional direct links between cap-and-trade systems is the need to harmonize cost-containment measures and reach mutual agreement about emissions caps. This may prove to be a particular challenge for a direct link between the EU ETS and North American capand-trade systems. For example, because California's system includes an allowance reserve, and RGGI's system includes a allowance price trigger for the use of additional offset credits, links to the EU ETS would result in automatic propagation of these cost control measures.

An additional obstacle to direct linkage is the diversity of stringency across systems. For example, a link between RGGI and the EU ETS is unlikely in the near future, given the current difference in allowance prices in the two systems (\$1.93 per allowance in RGGI versus $\$ 8.53$ per allowance in the EU ETS). ${ }^{23}$ Such a link would result in large capital flows from Europe to the United States, and could be perceived as Europeans subsidizing lackluster U.S. ambition.

Although the idea of linkage to a common credit system is also appealing, given that such a mechanism would not systems to harmonize design features, such linkage also faces some practical obstacles. First, most existing and planned cap-and-trade systems have placed restrictions on the use of offset credits. Table 1 summarizes these restrictions. The table shows, for example, that although many EU ETS participants have had relatively generous limits on credits for the 2008-2012 compliance period, future limits will allow credits to make up no more than half of aggregate EU ETS emissions reductions after 2013. Other systems have also imposed relatively low limits.

Second, although the CDM is currently the world's most important supplier of offset credits, it is not clear that it will continue in this role in the future. Beginning in 2013, the EU ETS - the largest source of demand for offset credits - will only accept new offsets from CDM projects in Least Developed Countries (LDCs). This requirement implies that China and India, which together have produced 68 percent of CDM offsets to-date, will no longer be eligible to sell CERs into the European market. What program or institution might replace the CDM is unknown. Recent UN discussions have centered around the possibility of "New Market Mechanisms," a vaguely defined set of sectoral crediting mechanisms that would require host country engagement and possibly emissions reduction commitments (International Emissions Trading Association 2012b). Other jurisdictions, such as California's AB 32 system, have begun developing other protocols for certifying emissions reduction credits from international sources.

A third set of obstacles to indirect linkage via a credit system are the policy goals - espoused by many European countries - of achieving domestic emissions reductions and promoting investment in renewable energy sources. Because allowing the use of credits has the effect of reducing allowance prices, linkage to a credit system (or even to a cap-and-trade system with a lower allowance price) reduces incentives for domestic firms to invest in renewable energy and other "green" technologies. The desire to achieve this separate policy goal may create political opposition to linkage. For example, European Commission documents reflect a clear concern that most emissions reduction be achieved domestically (European Parliament 2004, p.19; European Commission 2003, p.7-8; Kruger, Oats, and Pizer 2007, p.118). Such emphasis was also exhibited in the Kyoto Protocol: "The acquisition of emission reduction units shall be supplemental to domestic actions for the purposes of meeting commitments” (United Nations 1998).

\footnotetext{
${ }^{23}$ See http://www.pointcarbon.com/news/euets/ and
} 


\subsection{LONG-TERM ROLE}

In the long term, linkage could contribute to international climate policy architecture in at least two ways (Jaffe, Ranson, and Stavins 2009, p.803). First, linkage could serve as an element of a broader international climate architecture. In such a system, linkage might play several different roles. In the short term, indirect linkages via a common credit system might serve as an implicit framework that would provide market liquidity and some cost savings, while still allowing nations to maintain control over domestic allowance markets. In the longer term, nations might successfully negotiate a top-down climate agreement that specifies targets and timetables for emissions reductions. Such an architecture might include a more comprehensive set of multilateral linkages between industrialized and developing countries that would allow nations to achieve more stringent emissions targets at lower aggregate cost.

A second possibility is that a set of unilateral emissions commitments in a pledge-and-review system combined with a decentralized set of links could serve as a stand-alone, bottom-up architecture (Olmstead and Stavins 2012). As discussed above, the near-term outlines of such an architecture may already be emerging, with regional trading partners choosing to link directly with each other, with broader indirect linkages via the CDM or new sectoral crediting mechanisms, and with the Copenhagen Accord (United Nations 2009) and the Cancun Agreements (United Nations 2011) providing a pledge-and-review system of essentially voluntary national targets. As more jurisdictions establish cap-and-trade systems, this somewhat fragmented near-term system could evolve into a broader bottom-up architecture that includes a wide set of direct linkages.

Whether such a decentralized architecture could achieve meaningful environmental results in a cost-effective manner depends on several factors. First, a sufficient number of large emitters would have to agree to participate in the system. Participation by industrialized countries would need to be selfmotivated, and there are a number of potential incentives that might induce developing countries to participate. These include positive incentives ("carrots"), such as development assistance and the opportunity to sell allowances or offset credits, as well as negative incentives ("sticks"), such as carbon border adjustments or the imposition of graduation requirements as conditions for the opportunity to sell offset credits.

Second, participating nations would have to commit to substantial unilateral emissions reductions. In developed countries, these commitments would most likely be motivated by internal politics. In developing countries, commitments would most likely depend on participation incentives provided by developed countries. The emissions targets would either be decided unilaterally, or negotiated during the process of establishing and renewing direct linkages. The set of voluntary commitments made thus far under the Copenhagen Accord and the Cancun Agreements are probably insufficient for achieving the politically-endorsed international target of stabilizing greenhouse gas concentrations at $450 \mathrm{ppm} \mathrm{CO}_{2}$-equivalent (related to limiting average global warming to 2 degrees Centigrade) (Bosetti, Paltsev, Reilly, and Carraro 2011).

Third and finally, for such an international policy architecture to be cost-effective, it would require links among GHG trading systems in industrialized and developing countries. As discussed above, the near-term prospects for such a comprehensive set of links are mixed.

\section{Conclusion}

By replacing the United Nations Framework Convention on Climate Change’s Berlin Mandate, the Durban Platform for Enhanced Action has opened an important window. National delegations from around the world now have a challenging task before them: to identify by 2015 (for implementation in 2020) a new international climate policy architecture that is consistent with the process, pathway, and principles laid out in the Durban Platform. This will require finding a way to include all key countries in 
a structure that brings about meaningful emissions reductions on an appropriate timetable at acceptable cost, while remaining within the overall framework and principles provided by the UNFCCC.

On both a positive and normative basis, there is considerable attraction to bottom-up, decentralized international policy architectures. Among these, the most promising may be linkage among tradable permit systems, whether in the form of a near-term, de facto architecture of organic linkages among regional, national, and sub-national cap-and-trade systems, or in the form of a long-term replacement for the centralized, top-down architecture that characterizes the Kyoto Protocol. The Durban Platform has improved the likelihood of establishing the types of developed-developing country linkages necessary to support these climate architectures. 
Table 1: Summary of Limits on the Use of Offset Credits

\begin{tabular}{llll}
\hline \hline System & Period & $\begin{array}{l}\text { Limit as \% } \\
\text { of Cap }\end{array}$ & Notes \\
\hline \hline EU ETS & $2013-$ & TBD & (a) \\
EU ETS: Austria & $2008-2012$ & 10 & \\
EU ETS: Belgium & $2008-2012$ & 8.4 & \\
EU ETS: Czech Republic & $2008-2012$ & 10 & \\
EU ETS: Estonia & $2008-2012$ & 0 & \\
EU ETS: Finland & $2008-2012$ & 10 & \\
EU ETS: France & $2008-2012$ & 13.5 & \\
EU ETS: Hungary & $2008-2012$ & 10 & \\
EU ETS: Germany & $2008-2012$ & 12 & \\
EU ETS: Greece & $2008-2012$ & 9 & \\
EU ETS: Ireland & $2008-2012$ & 10 & \\
EU ETS: Italy & $2008-2012$ & 14.99 & \\
EU ETS: Latvia & $2008-2012$ & 10 & \\
EU ETS: Lithuania & $2008-2012$ & 20 & \\
EU ETS: Luxembourg & $2008-2012$ & 10 & \\
EU ETS: Malta & $2008-2012$ & n/a & \\
EU ETS: Netherlands & $2008-2012$ & 10 & \\
EU ETS: Poland & $2008-2012$ & 10 & \\
EU ETS: Slovakia & $2008-2012$ & 7 & \\
EU ETS: Slovenia & $2008-2012$ & 15.76 & \\
EU ETS: Spain & $2008-2012$ & 20 & \\
EU ETS: Sweden & $2008-2012$ & 10 & \\
EU ETS: United Kingdom & $2008-2012$ & 8 & (c) \\
Swiss ETS & $2008-$ & 8 & (d) \\
New Zealand ETS & $2008-$ & unlimited & \\
Australia's Clean Energy Act & $2012-$ & TBD & (b) \\
RGGI & $2009-$ & 3.3 & \\
California's CAT system & $2013-$ & 8 or 0 & \\
Quebec's CAT system & $2013-$ & 8 or 0 & \\
\hline \hline
\end{tabular}

Notes: (a) - The European Commission will choose a limit that allows credits to make up no more than $50 \%$ of emissions reductions. (b) From 2012 to 2015, the government may impose a fee of AUD\$15 to AUD\$17 per credit. (c) RGGI's limit rises to $5 \%$ if allowance prices exceed $\$ 7$, and to $10 \%$ if allowance prices exceed approximately \$10. (d) Neither California nor Quebec recognize offsets from UNFCCC flexibility mechanisms such as the CDM, although California has recently completed a MOA to allow deforestation credits from the states of Acre, Brazil, and Chiapas, Mexico.

Sources: See text above, and European Commission (2007c) 
Figure 1: Allowance Market with Binding Limit on Offsets

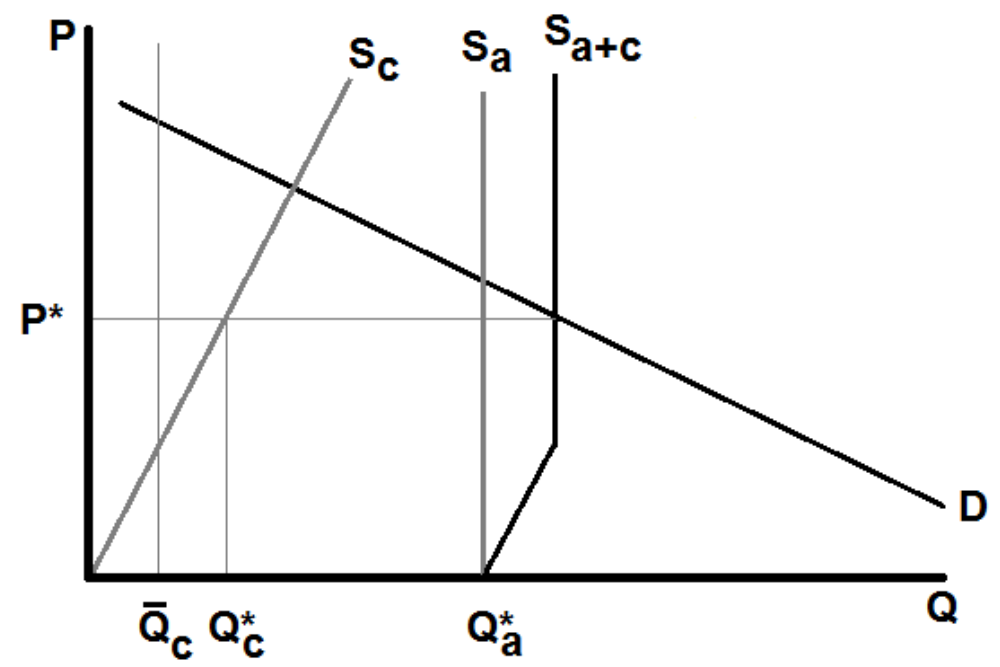

Legend: $\mathbf{D}$ represents demand for emissions permits. $\boldsymbol{S}_{\boldsymbol{a}}$ and $\boldsymbol{S}_{\boldsymbol{c}}$ represent the supply of domestic allowances and offset credits, respectively. $\boldsymbol{Q}_{c}$ represents the (binding) limit on offset sales. $\boldsymbol{S}_{\boldsymbol{a}+\boldsymbol{c}}$ represents aggregate supply of allowances and offset credits. $\mathbf{Q}_{\boldsymbol{a}}^{*}$ and $\boldsymbol{Q}^{*}{ }_{c}$ represent the number of allowances and credits that would be supplied at the market price $\mathbf{P}^{*}$. 


\section{REFERENCES}

Aldy, Joseph E., and Robert N. Stavins. 2010. Post-Kyoto International Climate Policy: Implementing Architectures for Agreement. New York: Cambridge University Press.

Aldy, Joseph, and Robert Stavins. 2012a. "Climate Negotiations Open a Window: Key Implications of the Durban Platform for Enhanced Action." Prepared for the Harvard Project on Climate Agreements, Cambridge, Massachusetts.

Aldy, Joseph, and Robert Stavins. 2012b. "The Promise and Problems of Pricing Carbon: Theory and Experience.” Journal of Environment and Development, forthcoming.

Australian Clean Energy Act. 2011. Available at http://www.comlaw.gov.au/Details/C2011A00131/ $\underline{\mathrm{Html} /}$

Australian Clean Energy International Unit Surrender Charge Act 2011, No. 158, 2011. Available at http://www.comlaw.gov.au/Details/C2011A00158/Download

Bloomberg. 2012. “South Korean Parliament Approves Carbon Trading System”. May 3. Available at http://www.bloomberg.com/news/2012-05-03/south-korean-parliament-approves-carbon-tradingsystem.html.

Bodansky, Daniel. 2011. "W[h]ither the Kyoto Protocol? Durban and Beyond.” Policy Brief, Harvard Project on Climate Agreements, Belfer Center for Science and International Affairs, Harvard Kennedy School.

Bosetti, Valentina, Sergey Paltsev, John Reilly, and Carlo Carraro. 2011. "Emissions Pricing to Stabilize Global Climate.” Nota di Lavoro 80.2011. Milan: Fondazione Eni Enrico Mattei.

Bruvoll, Annegrete, and Hanne Marit Dalen. 2009. "Pricing of $\mathrm{CO}_{2}$ Emissions in Norway." Statistics Norway. Available at http://www.ssb.no/emner/01/90/doc 200916/doc 200916.pdf

California Air Resources Board. 2012. "Discussion Draft, March 30, 2012: Amendments to the California Cap on Greenhouse Gas Emissions and Market-Based Compliance Mechanisms to Allow for the Use of Compliance Instruments Issued by Linked Jurisdictions." Available at http://www.arb.ca.gov/cc/capandtrade/draftregquebeclink.pdf

California Air Resources Board. 2011. “Overview of ARB Emissions Trading Program.” Available at http://www.arb.ca.gov/newsrel/2011/cap_trade_overview.pdf

California Code of Regulations, Subchapter 10 Climate Change, Article 5, "California Cap on Greenhouse Gas Emissions and Market-Based Compliance Mechanisms.” Available at http://www.arb.ca.gov/cc/capandtrade/finalregorder.pdf

Carbon Markets and Investors Association (CMIA). 2009. "Post-2012 Trading and Transfer of Assigned Amount Units.” Available at http://www.cmia.net/Portals/0/Repository/Post\%202012\%20trading\% 20\&\%20transfer\%20of\%20AAUs.4c0be919-8b07-4ccf-812d-18f007cd94f9.pdf 
CarbonPositive. 2007. "CER Prices Ease with EU Carbon.” February 15. Available at http://www.carbonpositive.net/viewarticle.aspx?articleID=670

CarbonPositive. 2008. "CER Market Steadies After Price Hit." November 10. Available at http://www.carbonpositive.net/viewarticle.aspx?articleID=1335

Combet, Greg, and Tim Grocer. 2011. "Joint Media Release: Australia and New Zealand Advance Linking of Their Emissions Trading Schemes." GC 333/11. Available at: http://www.climatechange.gov.au/ /media/Files/minister/combet/2011/media/december/MR2011120 $\underline{\text { BB.pdf. }}$

Combet, Greg. 2012. "Joint Media Release: Australia and Europe strengthen carbon market collaboration.” Available at http://www.climatechange.gov.au/ /media/Files/minister/combet/2012 /media/march/mr20120329b.pdf.

Convery, Frank, and Luke Redmond. 2007. "Market and Price Developments in the European Union Emissions Trading Scheme.” Review of Environmental Economics and Policy 1:66-87.

Council of the European Union. 2010. "EU to link its greenhouse gas emissions trading system with Switzerland.” Brussels, 20 December. 18085/10 PRESSE 353. Available at http://www.consilium.europa.eu/uedocs/cms_Data/docs/pressdata/en/envir/118632.pdf

Ellerman, Denny. 2010. “The EU Emission Trading Scheme: A Prototype Global System?” Post-Kyoto International Climate Policy: Implementing Architectures for Agreement, ed. Joseph E. Aldy and Robert N. Stavins, pp. 88-118. New York: Cambridge University Press.

Ellerman, A. Denny, and Barbara K. Buchner. 2007. "The European Union Emissions Trading Scheme: Origins, Allocation, and Early Results.” Review of Environmental Economics and Policy, volume 1, number 1, pp. 66-87.

Emissions Trading Scheme Review Panel. 2011. "Doing New Zealand’s Fair Share. Emissions Trading Scheme Review 2011: Final Report.” Wellington: Ministry for the Environment. Available at http://www.climatechange.govt.nz/emissions-trading-scheme/ets-review-2011/review-report.pdf

European Commission. 2003. "Proposal for a Directive of the European Parliament and of the Council amending the Directive establishing a scheme for greenhouse gas emission allowance trading within the Community, in respect of the Kyoto Protocol's project mechanisms.”

European Commission. 2005. “EU Action Against Climate Change: EU Emissions Trading.” Available at http://ec.europa.eu/environment/climat/pdf/emission_trading2_en.pdf

European Commission. 2007a. "Commission Decision of August 31, 2007 Concerning the National Allocation Plan for the Allocation of Greenhouse Gas Emission Allowances Notified by Denmark in Accordance with Directive 2003/87/EC of the European Parliament and of the Council.” COM (2005) 2515/6 final.

European Commission. 2007b. "Emissions trading: Commission announces linkage EU ETS with Norway, Iceland and Liechtenstein.”

European Commission. 2007c. "Emissions trading: Commission adopts decisions on amendments to five national allocation plans for 2008-2012.” Available at http://europa.eu/rapid/pressReleases 
Action.do?reference=IP/07/1094\&ampampformat=HTML\&ampampaged=0\&ampamplanguage=EN \&ampampguiLanguage $=$ en

European Commission. 2011a. "Questions and answers on use of international credits in the third trading phase of the EU ETS”. Available at http://ec.europa.eu/clima/policies/ets/linking/docs/q_ a 20111114 en.pdf.

European Commission. 2011b. "Emissions trading: Commission welcomes vote to ban certain industrial gas credits.” Available at http://europa.eu/rapid/pressReleasesAction.do?reference=IP/11/56.

European Commission. 2012a. “Emissions Trading System (EU ETS).” Available at http://ec.europa. eu/clima/policies/ets/index en.htm

European Commission. 2012b. “Allocation 2005-2012.” Available at http://ec.europa.eu/clima ppolicies/ets/allocation/index_en.htm

European Commission. 2012c. "Questions and answers on use of international credits in the third trading phase of the EU ETS”. Available at http://ec.europa.eu/clima/policies/ets/linking/docs/q _a_20111114_en.pdf.

European Parliament. 2004. "Directive 2004/101/EC of the European Parliament and of the Council." Official Journal of the European Union 2004(L 338): 18-23.

European Parliament. 2009. "Directive 2009/29/EC of the European Parliament and of the Council." Official Journal of the European Union 2009(L 140): 63-87.

Hahn, Robert W., and Robert N. Stavins. 1999. What Has the Kyoto Protocol Wrought? The Real Architecture of International Tradeable Permit Markets. Washington, D.C.: The AEI Press.

Han, Guoyi, Marie Olsson, Karl Hallding, and David Lunsford. 2012. "China's Carbon Emission Trading: An Overview of Current Development." Stockholm Environment Institute. http://www.sei-international.org/mediamanager/documents/Publications/china-cluster/SEI-FORES2012-China-Carbon-Emissions.pdf

Hall, Daniel S., Michael A. Levi, William A. Pizer, and Takahiro Ueno. 2010. "Policies for Developing Country Engagement.” Joseph E. Aldy and Robert N. Stavins, eds., Post-Kyoto International Climate Policy: Implementing Architectures for Agreement, pp. 649-681. New York: Cambridge University Press.

Helm, Carsten. 2003. “International Emissions Trading with Endogenous Allowance Choices.” Journal of Public Economics 87:2737-2747.

H.R.2454 - American Clean Energy And Security Act of 2009. Available at http://www.opencongress. org/bill/111-h2454/text

International Emissions Trading Association. 2012a. "Summary of Quebec's Regulation Respecting a Cap-and-Trade System for Greenhouse Gas Emission Allowance.” Available at http://www.ieta.org/ assets/ieta quebec\%20cap\%20and\%20trade\%20summary.pdf 
International Emissions Trading Association. 2012b. "IETA response to the AWG-LCA call for input regarding new market-based mechanisms”. Available at http://unfccc.int/resource/docs/2012/ smsn/ngo/168.pdf.

Jaffe, Judson, Matthew Ranson, and Robert N. Stavins. 2009. “Linking Tradable Permit Systems: A Key Element of Emerging International Climate Policy Architecture.” Ecology Law Quarterly 36: 789808.

Jaffe, Judson, and Robert N. Stavins. 2010. Linkage of Tradable Permit Systems in International Climate Policy Architecture.” Post-Kyoto International Climate Policy: Implementing Architectures for Agreement, ed. Joseph E. Aldy and Robert N. Stavins, pp. 119-150. New York: Cambridge University Press.

Karpas, Eric, and Suzi Kerr. 2011. "Preliminary Evidence on Responses to the New Zealand Forestry Emissions Trading Scheme.” Motu Working Paper 11-09. Available at http://www.motu.org.nz/publications/detail/preliminary_evidence_on_responses_to_the_new_zealan d_forestry_emissions_tra.

Kruger, Joseph, Wallace Oates, and William Pizer. 2007. "Decentralization in the EU Emissions Trading Scheme and Lessons for Global Policy.” Review of Environmental Economics and Policy 1(1): 112133.

Mace, M.J., Ilona Millar, Christoph Schwarte, Jason Anderson, Derik Broekhoff, Robert Bradley, Catherine Bowyer, and Robert Heilmayr. 2008. "Analysis of the Legal and Organisational Issues Arising in Linking the EU Emissions Trading Scheme to Other Existing and Emerging Emissions Trading Schemes.” Study Commissioned by the European Commission DG-Environment, Climate Change and Air. Available at http://www.field.org.uk/files/Linking\%20emission\%20trading\%20 schemes_0.pdf

Market Advisory Committee to the California Air Resources Board. 2007. "Recommendations for Designing a Greenhouse Gas Cap-and-Trade System for California.”

Metcalf, Gilbert, and David Weisbach. 2012. "Linking Policies When Taste Differ: Global Climate Policy in a Heterogeneous World.” Review of Environmental Economics and Policy 6(1): 110-129.

Montagnoli, Alberto, and Frans de Vries. 2010. "Carbon trading thickness and market efficiency." Energy Economics 32(6): 1331-1336.

Morris, Daniel F., Nathan Richardson, and Anne Riddle. 2011. "Importing Climate Mitigation: The Potential and Challenges of International Forest Offsets in California Climate Policy.” Available at: http://www.rff.org/RFF/Documents/RFF-IB-11-12\%20\%282\%29.pdf.

New Zealand Herald. 2011. "NZ-Europe ETS link a long way off, says official.” April 6. Available at http://www.nzherald.co.nz/economy/news/article.cfm?c_id=34\&objectid=10715758

New Zealand Ministry for the Environment. 2007. "The Framework for a New Zealand Emissions Trading Scheme.” Publication Number ME 810. Available at http://www.mfe.govt.nz/publications/ climate/framework-emissions-trading-scheme-sep07/framework-emissions-trading-scheme-sep07. pdf 
New Zealand Ministry for the Environment. 2012. "Guidance on the use of CERs in the NZ ETS." Available at http://climatechange.govt.nz/emissions-trading-scheme/building/regulatory-updates/ guidance-identifying-banned-restriction-cers.pdf

New Zealand Parliament. 2011. “Climate Change Response Act 2002, as Amended 5 December 2011.”

Nordhaus, William D. 2008. A Question of Balance. New Haven, CT: Yale University Press.

Norway Ministry of the Environment. 2009. "Norway`s Fifth National Communication under the Framework Convention on Climate Change: Status report as of December 2009.” Available at http://www.regjeringen.no/upload/MD/Vedlegg/Rapporter/T-1482E.pdf

“Norwegian National Allocation Plan for the Emissions Trading System in 2008-2012.” Available at http://www.regjeringen.no/Upload/MD/Vedlegg/Horinger/Allokeringsplan/Norwegian_National_All ocation_Plan_for_the_emissions_trading_system_in_2008_2012.pdf

Olmstead, Sheila M., and Robert N. Stavins. 2012. “Three Key Elements of Post-2012 International Climate Policy Architecture.” Review of Environmental Economics and Policy, Winter 2012, Volume 6, Number 2, pages 1-22.

Petherick, Anna. 2012. “Sweetening the dragon's breath.” Nature Climate Change 2: 309-311.

Point Carbon Advisory Services, New Zealand Emissions Trading Group. 2007. "Issues in the International Carbon Market, 2008-2012 and Beyond.” Available at http://www.mfe.govt.nz/ publications/climate/issues-international-carbon-market-oct07/issues-international-carbon-market07.pdf.

PointCarbon. 2012a. "RGGI Officials to Weigh Lower Caps.” Carbon Market North America 7(10): 3.

PointCarbon. 2012b. "Switzerland sees EU ETS link in 2014." Available at http://www.pointcarbon. com/news/1.1861881.

PointCarbon. 2012c. “California lawmakers seek delay to Quebec ETS link”. Carbon Market North America 7(20): 1.

Posner, Eric, and David Weisbach. 2010. Climate Change Justice. Princeton University Press: Princeton, NJ.

Quebec Government. 2011. "Regulation Respecting a Cap-and-Trade System for Greenhouse Gas Emission Allowances.” Available at http://www.mddep.gouv.qc.ca/changements/carbone/reglement PEDE-en.pdf

Quebec Office of the Minister of Sustainable Development, Environment, and Parks. 2011. "Press Release: Adoption of the Regulation Respecting the Cap-And-Trade System for Greenhouse Gas emission Allowances.” Available at http://www.mddep.gouv.qc.ca/communiques_en/2011 /c20111215-carbonmarket.htm

Regional Greenhouse Gas Initiative. 2006a. “Analysis Supporting Offsets Limit Recommendation.” Available at http://www.rggi.org/docs/offsets_limit_5_1_06.pdf 
Regional Greenhouse Gas Initiative. 2006b. "Amendment to Memorandum of Understanding." Available at http://www.rggi.org/docs/mou_8_8_06.pdf

Regional Greenhouse Gas Initiative. 2007. "Model Rule.” Regional Greenhouse Gas Initiative Model Rule. Available at http://rggi.org/docs/model_rule_corrected_1_5_07.pdf

Regional Greenhouse Gas Initiative. 2010a. “About the Regional Greenhouse Gas Initiative.” Available at http://www.rggi.org/docs/RGGI_Fact_Sheet.pdf

Regional Greenhouse Gas Initiative. 2010b. "Fact Sheet: RGGI CO $\mathrm{CO}_{2}$ Allowance Auctions.” Available at http://www.rggi.org/docs/RGGI Auctions in Brief.pdf

Regional Greenhouse Gas Initiative $\mathrm{CO}_{2}$ Allowance Tracking System. 2012a. “Offset Projects.” Available at https://rggi-coats.org/eats/rggi/index.cfm?fuseaction=search.project_offset\&clearfuse $\underline{\text { attribs=true }}$

Regional Greenhouse Gas Initiative $\mathrm{CO}_{2}$ Allowance Tracking System. 2012b. "Transaction Price Report.” Available at https://rggi-coats.org/eats/rggi/index.cfm?fuseaction=reportsv2.price_rpt\& clearfuseatt ribs=true

Reuters. 2011. “Slovakia eyes AAU sales to Spain: Point Carbon.” Available at: http://www.reuters. com/article/2011/12/21/us-carbon-slovakia-aau-idUSTRE7BK17V20111221

Reuters. 2012. "NZ spot carbon prices recover from sell-off.” Available at: http://www.reuters. com/article/2012/03/02/newzealand-carbon-idUSL4E8E171W20120302

Swiss Federal Office for the Environment (FOEN). 2007. "Emission Credits, Offsetting and Trading." Available at http://www.bafu.admin.ch/emissionshandel/05545/05547/index.html?lang=en

UNEP Risoe Centre. 2012. “Status of JI Projects.” Available at http://cdmpipeline.org/ji-projects.htm

United Nations. 1992. United Nations Framework Convention on Climate Change, Article 3, paragraph 1; emphasis added. Internet: http://unfccc.int/resource/docs/convkp/conveng.pdf.

United Nations. 1995. Berlin Mandate. Decision 1/CP.1, U.N. Framework Convention on Climate Change. Internet: http://unfccc.int/resource/docs/cop1/07a01.pdf.

United Nations. 1998. Kyoto Protocol to the United National Framework Convention on Climate Change. Available at http://unfccc.int/resource/docs/convkp/kpeng.pdf

United Nations. 2009. Copenhagen Accord. Decision 2/CP.15, U.N. Framework Convention on Climate Change. Internet: http://unfccc.int/resource/docs/2009/cop15/eng/107.pdf.

United Nations. 2010. The Cancun Agreements. Decision 1/CP.11, U.N. Framework Convention on Climate Change. Internet: http://unfccc.int/resource/docs/2010/cop16/eng/07a01.pdf.

United Nations. 2011. Establishment of an Ad Hoc Working Group on the Durban Platform for Enhanced Action. Decision 1/CP.17, U.N. Framework Convention on Climate Change. Internet: http://unfccc.int/files/meetings/durban_nov_2011/decisions/application/pdf/cop17_durbanplatform.p df. 
United Nations Framework Convention on Climate Change. 2012a. "Registered projects by AI and NAI Parties.” Available at http://cdm.unfccc.int/Statistics/Registration/RegisteredProjAnnex1Parties PieChart.html

United Nations Framework Convention on Climate Change. 2012b. "CERs issued by host party." Available at http://cdm.unfccc.int/Statistics/Issuance/ CERsIssuedByHostPartyPieChart.html

U.S. Energy Information Administration. 2011. Annual Energy Outlook 2011. Washington, D.C.

Wara, Michael. 2007. “Is the Global Carbon Market Working?” Nature, volume 445, 8 February, pp. 595-596.

Zhang, Junjie, and Can Wang. 2011. "Co-Benefits and Additionality of the Clean Development Mechanism: An Empirical Analysis." Journal of Environmental Economics and Management 62:140-154. 